\title{
Психолого-педагогічні засади формування професійних компетентностей майбутніх офіцерів-психологів
}

Вклад Авторів:

A - Study design;

B - Data collection;

C - Statistical analysis;

D - Data interpretation;

E - Manuscript preparation;

F - Literature search;

G - Funds collection

G-Funds collection

Вступ та

Мета дослідження:

Матеріали і Методи:

Результати:

Висновки:

Ключові слова:

Копірайт:

DOI та УДК

Конфлікт інтересів:

Рецензування:

Джерело фінансування: Інформація про авторів:
Бабак С. А. 1 ABDEG

Стаднік А. В. ${ }^{1,2}$ ABDEFG, Мельник Ю. Б. ${ }^{2,3}$ ADEFG

${ }^{1}$ Харківський національний університет внутрішніх справ, Украӥна

${ }^{2}$ Харківська обласна громадська організачія “Культура Здоров'я” (ХОГОКЗ), Україна

${ }^{3}$ Науково-дослідний інститут ХОГОКЗ, Украӥна

Отримано: 08.08.2020; Прийнято: 17.09.2020; Опубліковано: 30.09 .2020

\section{Анотація}

Підготовка майбутніх офіцерів-психологів на військовій кафедрі закладу вищої освіти (3ВО) передбачає формування низки компетентностей, однією із важливих є професійна компетентність. Це передбачає вирішення певних завдань щзодо якісної підготовки офіцерів-психологів, поліпшення викладання у військових ЗВО та покращення організащії та методики роботи з особовим складом Збройних Сил Украӥни. Мета дослідження: визначити психолого-педагогічні засади формування професійних компетентностей майбутніх офіцерів-психологів під час навчання на військовій кафедрі $3 В О$ та на иій основі розробити модель формування професійної компетентності.

Методологія дослідження базується на компетентністному підході до формування професійно значущих якостей майбутніх офіиерів-психологів. Аналіз $і$ узагальнення психолого-педагогічної, науково-методичної літератури з проблем організачії навчання на військовій кафедрі ЗВО, розробка моделі професійноі компетентності майбутнього військового психолога для вирішення компетентністно-оріснтованих задач в освітньому процесі.

Визначено, щчо специфіка професійної діяльності майбутніх офіцерів-психологів має стійку та потужну психолого-педагогічну складову, яка містить: психологічну діагностику, психологічну прогностику, психологічну профілактику, психологічне консультування, психологічну корекцію, психологічну реабілітацію, психологічний відбір та розстановку кадрів, просвітницько-пропагандистську та дослідницьку роботу, психологічну експертизу. Уточнено структуру складових професійної компетентності офіиера-психолога. 3'ясовано психолого-педагогічні засади формування професійної компетентності офіцера-психолога, які становлять зміст умовної складової моделі професійної компетентності майбутнього військового психолога та містять три взаємопов'язаних між собою блоки: иільовий, змістовий, результативний.

Визначені психолого-педагогічні засади формування професійної компетентності офіцера-психолога розглядаються як ефективний інструментарій організаиіі системи підготовки офіиера-психолога. Запропонована модель професійной компетентності майбутнього військового психолога $\epsilon$ відкритою, постійно розвивається та за необхідністю може бути доповнена новими компонентами. освіта, психологи, офіиери, компетентність, модель

(C) 2020 Бабак С. А., Стаднік А. В., Мельник Ю. Б. Опубліковано в архівах Міжнародного журналу освіти і науки

DOI 10.26697/ijes.2020.3.4; УДК 159.9:37.013.77:355.23:005.336.2

Автори заявляють про відсутність конфлікту інтересів

Подвійне "сліпе"

Це дослідження не отримало жодного зовнішнього фінансування чи підтримки

Бабак Серхій Анатолійович - https://orcid.org/0000-0002-2248-454X; кандидат військових наук, старший науковий співробітник, завідувач кафедри військової підготовки, Харківський національний університет внутрішніх справ, Украӥна.

Стаднік Анатолій Володимирович (Автор-Кореспондент) https://orcid.org/0000-0002-1472-4224; stav1963@ukr.net; кандидатмедичних наук, дочент, Харківський національний університет внутрішніх справ, Украйна.

Мельник Юрій Борисович - https://orcid.org/0000-0002-8527-4638; доктор філософії з освітніх наук, доцент; Засновник і Голова Правління, ХОГОКЗ; Директор, Науково-дослідний інститут ХОГОКЗ, Харків, Украӥна. 
Вступ

Забезпечення відповідної якості підготовки фахівців для Збройних Сил України (ЗСУ) є одним 3 пріоритетних завдань для закладів вищої освіти, особливо в умовах проведення Операції Об'єднаних сил на Донбасі. Реалії сьогоднішнього дня поставили на порядок денний питання підготовки для українського війська офіцерів нового покоління - патріотично налаштованих та професійно-компетентних. Це $\epsilon$ можливим виключно в разі отримання ними якісної освіти.

Підготовка майбутніх офіцерів-психологів на військовій кафедрі вишу передбачає формування низки компетентностей, однією із важливих $\epsilon$ професійна компетентність. Все це передбачає вирішення певних завдань щодо якісної підготовки офіцерів-психологів, поліпшення викладання у військових вишах та покращення організації та методики роботи 3 особовим складом ЗСУ. Вітчизняні дослідники вказують, що навчання у вищій військовій школі необхідно підкорити єдиному завданню - формуванню та розвитку професійних якостей майбутнього офіцера (Осьодло, 2012; Стаднік, Рютін, Міршук, \& Прокопенко, 2018; Ягупов, 2002).

Мета дослідження. Визначити психологопедагогічні засади формування професійних компетентностей майбутніх офіцерів-психологів під час навчання на військовій кафедрі закладу вищої освіти та на цій основі розробити модель формування професійної компетентності.

Матеріали і Методи
Методологія дослідження базується на
компетентністному підході до формування
професійно значущих якостей майбутніх офіцерів-
психологів. Аналіз і узагальнення психолого-
педагогічної, науково-методичної літератури 3
проблем організації навчання на військовій кафедрі
ЗВО, розробка моделі професійної компетентності
майбутнього військового психолога для вирішення
компетентністно-орієнтованих задач в освітньому
процесі.

\section{Результати та Обговорення}

Аналіз літератури засвідчив, що проблема формування професійної компетентності фахівців у процесі їхньої підготовки у закладі вищої освіти 3 позицій компетентнісного підходу має тривалу історію (Hamel \& Prahalad, 1990) і знайшла своє відбиття у працях багатьох дослідників: Kallioinen (2010); Костіної (2016); Melnyk (2017), зокрема питання формування й розвитку професійних компетентностей у військових закладах вищої освіти досліджувались Лемешко (2016); Стадніком та іншими (2018). Психологічні та педагогічні особливості формування професійної компетентності майбутніх офіцерів були об'єктом досліджень: Артюшина (2016); Мельника та Стадніка (2020); Melnyk, Prykhodko, and Stadnik (2019), інших.
Аналіз теоретичних напрацювань українських військових психологів, практичного досвіду підготовки та вимог, що висуваються до психологічної освіти курсантів психологічного профілю, дав змогу виявити існування певних суперечностей, зокрема між:

- об’єктивною потребою українського війська в підготовці висококваліфікованих і професійнокомпетентних фахівців для ЗСУ та недостатніми можливостями сучасної системи військової освіти; - необхідністю реалізації сучасної компетентнісної концепції професійної освіти та удосконаленням психолого-педагогічних розробок щодо інноваційної підготовки психологів у військових вишах;

- вимогами державних стандартів до рівня психологічної компетентності випускників військових вишів та недостатньою методичною готовністю науково-педагогічних працівників до реалізації визначених завдань;

- суперечність між знаннями, які набувають курсанти (студенти), та вмінням їх застосовувати (Осьодло, 2012).

Вважаємо, що компетентнісний підхід щодо формування змісту професійної підготовки майбутніх офіцерів-психологів дозволить усунути зазначені недоліки, оскільки його ключовим положенням є посилення практичної спрямованості освіти.

Компетентність фахівця, як зазначає Драч (2013), є складною інтегрованою характеристикою особистості, яка зумовлює іiі здатність до реалізації власного потенціалу (знань, умінь, досвіду, особистісних якостей) для успішної діяльності у професійній та соціальній сфері, усвідомлюючи соціальну значимість i особистісну відповідальність за результати цієї діяльності, необхідність ії постійного удосконалення в умовах динамічного світу. Звідси випливає, що компетентність $є$ раціональним поєднанням знань, здібностей та готовності до діяльності, оріснтованих на самостійну участь особи у навчально-пізнавальному процесі й подальше успішне використання у професійній діяльності.

Вже багато років та до нині питання формування компетентності фахівця перебуває в центрі уваги численних спільних педагогічних та психологічних досліджень, використовуються різні методологічні підходи та методи. Емпіричні дані свідчать про ефективність підготовки фахівця може відбуватися через проблемне навчання у освітньому процесі (Belland, Walker, Kim, \& Lefler, 2017; Dochy, Segers, van den Bossche, \& Gijbels, 2003), здійснюються дослідження щодо можливості розвитку діагностичних компетенцій у педагогічній освіті (Chernikova et al, 2020). Цифрові компетентності у вищій освіті досліджені Mengual-Andrés, Roig-Vila, and Mira (2016). Придбання наскрізних компетенцій у вищій освіті вивчалось Alcalá, Picos, and Pastor (2019). 
Оцінка формування компетентностей у вищій освіті в автентичному навчальному середовищі досліджувалось Keinänena, Ursinb, and Nissinen (2018). Вищенаведені праці та мета-аналізи емпіричних досліджень цих авторів дають змогу 3'ясувати психолого-педагогічні особливості організації навчання та на цій основі розробити моделі професійної компетентності майбутнього військового психолога.

У психологічній освіті поняття “професійна компетентність” використовується по-різному. Так само, як у загальній освіті та психології, до цього часу існує суперечливий підхід до самого поняття “компетентність” (Стаднік та інші, 2018).

Ми розглядаємо поняття "професійна компетентність офіцера-психолога" як здатність від початку професійної діяльності розуміти характер професійних проблем, освоювати i розвивати інноваційні технології, набувати й використовувати знання, інтегрувати їх та передавати їх у процесі комунікації 3 клієнтом і колегами, приймати та реалізовувати правильні й відповідальні рішення, керуючись морально-етичними принципами, володіти методами моделювання і самоконтролю, уміти ефективно працювати у підрозділі (групі), реалізовувати свій потенціал (знання, уміння, досвід, ділові, особистісні якості й самооцінку), постійно саморозвиватися і самоудосконалюватися у продуктивній професійній діяльності.

Компетентнісний підхід до підготовки майбутніх фахівців полягає в набутті та розвитку у курсантів/студентів під час навчання набору ключових, загально-галузевих та предметних компетентностей, які визначають їх успішну професійну діяльність. Ми вважаємо, що професійна компетентність військового психолога формується на основі базових психологічних навичок, наукового знання і морального розвитку. Ïї головними компонентами є здатність набувати i використовувати знання, інтегрувати їх за допомогою професійного мислення, а також реалізовувати і передавати у процесі комунікації 3 клієнтами i колегами, керуючись моральноетичними принципами. Тобто професійна компетентність майбутніх офіцерів-психологів - це єдність теоретичної підготовки та їх готовність на службі до здійснення професійної діяльності.

Специфіка майбутньої професійної діяльності майбутніх офіцерів-психологів має стійку та потужну психологічну складову (рисунок 1).

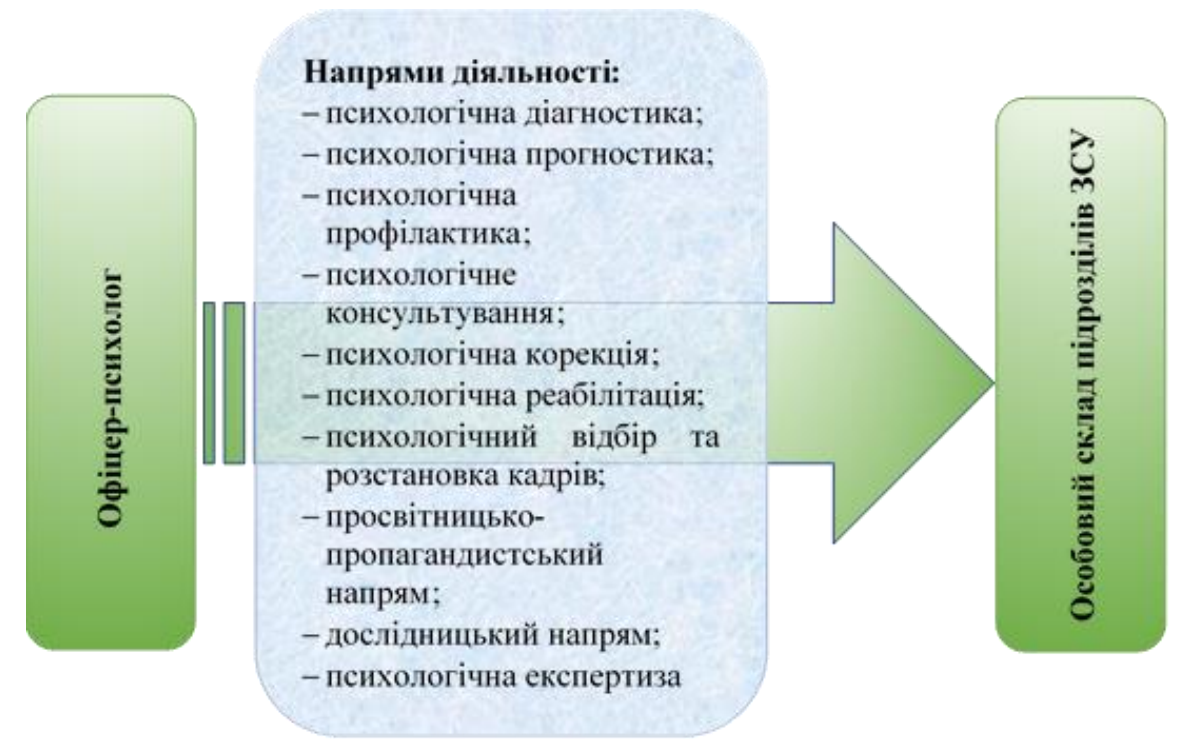

Рисунок 1. Професійна діяльність військового психолога.

Аналіз наукових праць та педагогічного досвіду переконують, що складовими компетентності є: мотивація, знання, діяльність та досвід. Де мотивація - це спонукання до дії, оскільки реалізація компетенцій відбувається у процесі виконання різних видів діяльності для вирішення теоретичних i практичних завдань; знання сукупність інформації щодо здійснення певних дій; діяльність - сукупність умінь та способів дій; а досвід - інтеграція в єдине ціле засвоєних окремих дій, способів та прийомів вирішення завдань. Звідси витікає, що компетентність не є сталим показником фахівця, вона змінюється відповідно до умов сучасного світу, має діяльнісний характер узагальнених умінь та навичок.
Для розкриття змісту професійної компетентності офіцера-психолога істотним є змістовне визначення ключових компетенцій, яких повинні набути курсанти/студенти як для успішної службовопрофесійної діяльності, так і для подальшого формування особи.

Ми пропонуємо наступну структуру професійної компетентності офіцера-психолога: загальновійськова компетентність, психологопедагогічна, соціально-комунікативна, моральноетична, акмеологічна, організаційно-правова, науково-технічна та фізична компетентність (рисунок 2). 


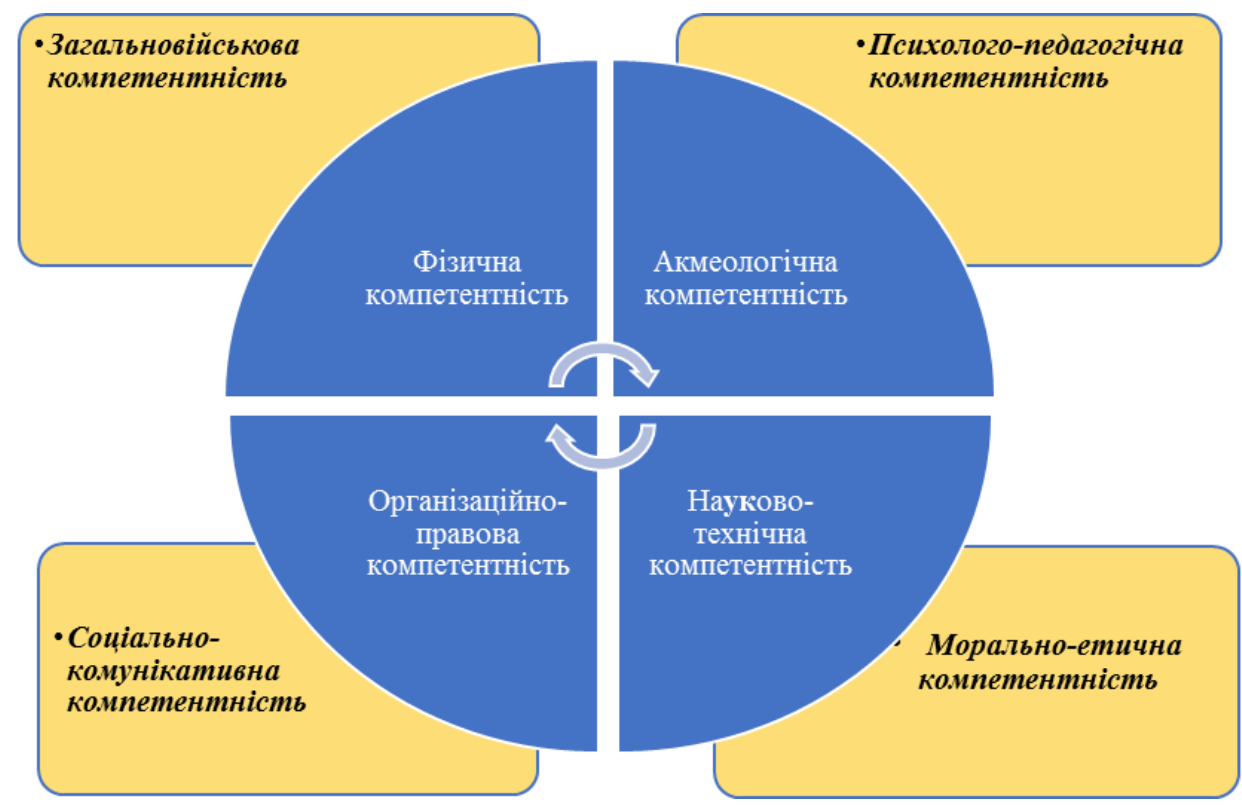

Рисунок 2. Складові професійної компетентності офіцера-психолога.

Загальновійськова компетентність передбачає, що курсанти/студенти повинні оволодіти знаннями щодо: законодавства ЗСУ (трактування основних положення військового законодавства), статутів ЗСУ (застосовування основних положення статутів ЗСУ при організації внутрішньої, гарнізонної та вартової служби і організації побуту особового складу підрозділу), загальної тактики (основи сучасного загальновійськового бою; організація бойової підготовки; бойова готовність підрозділів), стройової підготовки (виконання стройових прийомів без зброї та зі зброєю), вогневої підготовки (вивчення матеріальної частини зброї, основ і правил стрільби, дій зі зброєю, прийомів стрільби, прийомів i правил метання ручних гранат), топографії (вивчення основ військової топографії, орієнтування на місцевості; правила ведення робочої карти офіцера).

Психолого-педагогічна компетентність передбачає, що курсанти/студенти повинні засвоїти наступні знання та уміння 3: психологічної допомоги (психологічна діагностика, психологічне консультування психологічна корекція, екстрена психологічна допомога), психопрофілактичної роботи (пропаганда здорового способу життя на власному прикладі, запобігання особистісним i груповим негативним психологічним явищам, які виникають в процесі проходження військової служби та виконання бойових завдань), організаційної діяльності (ведення психологічної документації), методики роботи 3 особовим складом в підрозділі (організація та методика роботи 3 гуманітарних питань, моральної та психологічної підготовки особового складу підрозділу при проведенні бойового злагодження і в основних видах бойової діяльності військ), педагогічної діяльності (систематичне проведення занять 3 професійної підготовки, професійне педагогічне керівництво підлеглими), а також свідомо планувати свою майбутню професійну освіту,

Соціально-комунікативна компетентність відображає можливості офіцера-психолога до спілкування всередині чіткої військової ієрархії, навички організації та керівництва особовим складом, особисті лідерські якості. У межах комунікативної компетенції військовий психолог повинен доступно пояснити клієнту (його родичам) про стан його психічного здоров'я, пояснити необхідність певних психологічних процедур, спілкуватися 3 колегами. Також соціальнокомунікативна компетентність надає вміння вирішувати різні соціально- психологічні проблеми (девіантна поведінка, делінквентна поведінка. адиктивна поведінка та ін.), навички професійно діяти в складі підрозділу/команди, надавати необхідну психологічну допомогу клієнтам незалежно від їх військового звання, посади, освіти, релігійних поглядів, раси та ін.

Морально-етична компетентність відображає морально-статусні відносини офіцера-психолога, передбачає наявність патріотичних моральноетичних знань та цінностей служіння Батьківщині. Вона формує у курсантів/студентів ціннісні орієнтації та особистісні сенси, завдяки яким вони на практиці будуть керуватимуться принципами совісті та співчуття, любові до Батьківщини, самопожертви, бачитимуть у клієнтові особистість, а не матеріал для психологічної роботи.

Акмеологічна компетентність полягає у здатності до швидкого реагування на мінливі умови службово-бойової діяльності та пристосування до них, творчій самореалізації, активності, ініціативі та саморозвитку.

Організаційно-правова компетентність передбачає організацію виконання управлінських рішень, розвиток лідерських якостей та забезпечує рівномірне навантаження на підлеглих; вона передбачає знання законодавства, нормативних 
актів, наказів, інструкцій щодо професійної діяльності, розуміння їх відповідності інтересам Вітчизни i законним правам та обов'язкам військовослужбовця, вміння застосовувати їх на практиці.

Науково-технічна компетентність - сприяє у проведенні наукових досліджень у галузі психології та впровадження їх результатів у практичну діяльність, наявність знань військової та комп’ютерної техніки, можливостей застосування іiі для психологічної діагностики, надання психологічної допомоги та виконання службовобойових завдань.

Фізична компетентність - фізична підготовленість, фізична відповідність офіцера-психолога виконанню завдань військової служби.

Необхідність обліку психофізіологічних особливостей курсантів під час навчання у вищих військових закладах освіти та можливості збереження психічного здоров'я розкрито в публікаціях авторами Melnyk and Stadnik (2017; 2018).

Формування професійної компетентності офіцерапсихолога здійснюється через зміст освіти, яка містить не лише теоретичну частину, але й практичну, що сприяє формуванню професійних навичок й умінь, які формуються у процесі опанування предмета, а також за допомогою активної самостійної роботи курсанта/студента.

Психолого-педагогічні засади формування професійної компетентності офіцера-психолога становлять головний зміст умовної складової моделі формування професійної компетентності майбутнього військового психолога: Спираючись на дослідження Артюшина (2016) щодо інтеграції фахових і психологічних складових у структурі професійної компетентності військовослужбовців, об'єднаємо їх у три взаємопов'язаних між собою блоки (рисунок 3):

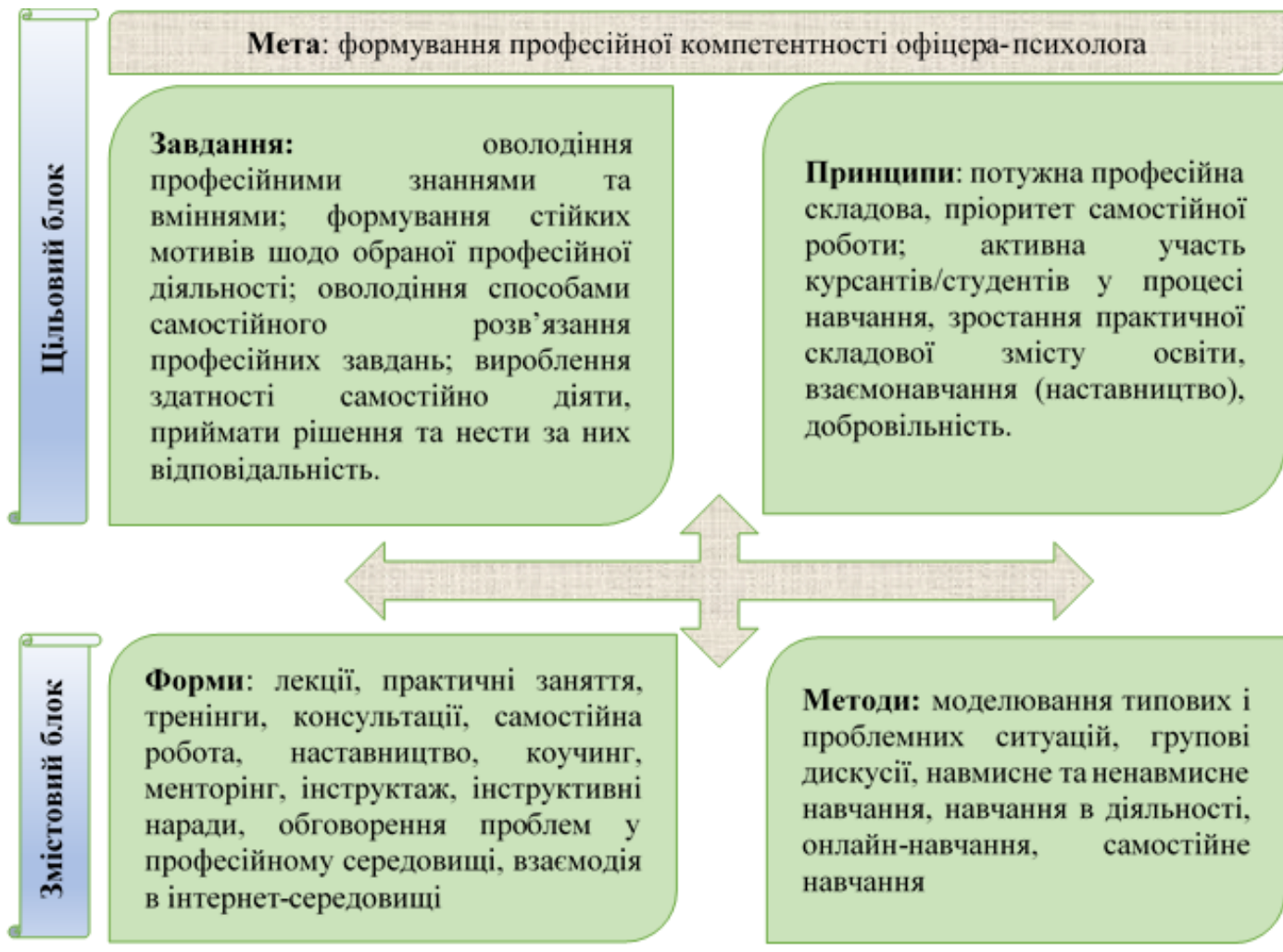

Критерії сформованості: когнітивний- наявність професійних знань, розуміння цілей та завдань професійної діяльності; діяльнісний - наявність професійних умінь, необхідних для виконання посадових функцій, оволодіння способами й досвідом самостійного розв'язання професійних завдань; особистісний - наявність професійно важливих особистісних якостей, усвідомлення значущості своєї діяльності, орієнтація на професійне самовдосконалення; рефлексиєний - здатність до критичного аналізу професійних труднощів, професійна мобільність, готовність до подальшого навчання

Рівні сформованості: високий, середній, низький

Результат: сформованість професійної компетентності офіцера-психолога

Рисунок 3. Модель формування професійної компетентності офіцера-психолога. 
- цільовий блок - передбачає визначення мети, завдань та принципів формування професійної компетентності майбутнього військового психолога;

- змістовий блок включає форми та методи проведення навчання, використання практикоорієнтованих технологій, інтерактивних форм та методів навчання, коригування змісту навчальних занять, інтеграцію різноманітних дисциплін та спецкурсів;

- результативний блок - визначає критерії та рівні сформованості професійної компетентності військового психолога, коригування контрольнооцінювальних підходів до результатів навчання, визначення груп умінь, якими повинен володіти компетентний офіцер-психолог.

Для визначення ефективності функціонування розробленої моделі нами встановлені рівні сформованості професійної компетентності майбутнього військового психолога - низький або алгоритмічний, середній або евристичний, високий або творчий.

Результуюча складова моделі передбачає наявність конкретних результатів реалізації процесу формування професійної компетентності майбутнього військового психолога - перехід на більш високий рівень професійної компетентності.

\section{Висновки}

Отже, специфіка професійної діяльності майбутніх офіцерів-психологів має стійку та потужну психолого-педагогічну складову, що містить: психологічну діагностику, психологічну прогностику, психологічну профілактику, психологічне консультування, психологічну корекцію, психологічну реабілітацію, психологічний відбір та розстановку кадрів, просвітницько-пропагандистську та дослідницьку роботу, психологічну експертизу.

Професійна компетентність офіцера-психолога, на нашу думку, має наступну структуру: загальновійськова психолого-педагогічна, соціально-комунікативна, морально-етична, акмеологічна, організаційно-правова, науковотехнічна та фізична.

Психолого-педагогічні засади формування професійної компетентності офіцера-психолога становлять зміст умовної складової моделі професійної компетентності майбутнього військового психолога та містять три взаємопов'язаних між собою блоки: цільовий блок (мета, завдання та принципи формування професійної компетентності військового психолога); змістовий блок (форми та методи проведення навчання, використання практикоорієнтованих технологій, інтерактивних форм та методів навчання); результативний блок (критерії та рівні сформованості професійної компетентності військового психолога, коригування контрольнооцінювальних підходів до результатів навчання, визначення груп умінь, якими повинен володіти компетентний офіцер-психолог).
Таким чином, визначені психолого-педагогічні засади формування професійної компетентності офіцера-психолога розглядаються як ефективний інструментарій організації системи підготовки компетентного військового психолога. Запропонована модель $є$ відкритою, постійно розвивається та за необхідністю може бути доповнена новими компонентами..

\section{Джерело фінансування}

Це дослідження не отримало жодного гранту від будь-якого фінансового агентства в державному, комерційному чи некомерційному секторах.

\section{Література}

Артюшин Г. М. Інтеграція фахових і психологічних складових у структурі професійної компетентності співробітників органів сектору безпеки та оборони України. Професійна освіта: проблеми і перспективи. 2016. Вип. 10. С. 5-11.

Драч I. Компетентність фахівця як теоретична проблема. Нова педагогічна думка. 2013. № 3. C. 41-44.

Костіна В. В. Етнізація освітнього середовища підготовки майбутніх фахівців соціальної сфери як умова підвищення їх професійної компетентності у роботі з дезадаптованими дітьми та молоддю. Педагогізачія соияіального середовища в роботі з різними сочіальними суб'єктами: матеріали наук.практ. конф., 22 лист. 2016 р. Харків: ХНПУ, 2016. C. 59-61.

Лемешко О. В. Професійна компетентність як складова готовності майбутніх офіцерівприкордонників до локалізації нестандартних ситуацій в пунктах пропуску через державний кордон. Військова освіта Національного університету оборони України імені Івана Черняховського. 2016. № 1(33). С. 42-49.

Мельник Ю. Б., Стаднік А. В. Вплив негативних психологічних факторів на ефективність роботи військовослужбовців в екстремальних умовах. International Journal of Education and Science. 2020. Vol. 3. No. 2. P. 40. doi:10.26697/ijes.2020.2.26

Осьодло В. I. Психологія професійного становлення офіцера: монографія. Київ: Золоті Ворота, 2012. $463 \mathrm{c}$.

Шляхи формування професійних компетентностей курсантів психологічного профілю у процесі навчання/А. В. Стаднік та ін. Честь $i$ закон. 2018. № 3. C. 45-50.

Ягупов В. В. Педагогіка: навч. посіб. Київ: Либідь, $2002.560 \mathrm{c}$.

Alcalá D. H., Picos A. P., Pastor V. L. The impact of formative and shared or co-assessment on the acquisition of transversal competences in higher education. Assessment \& Evaluation in Higher Education. 2019. Vol. 44. No. 6. P. 933-945. doi:10.1080/02602938.2018.1530341 
Effects of problem-based learning: A metaanalysis/Dochy $\mathrm{F}$. et al. Learning and Instruction. 2003. Vol. 13. Issue 5. P. 533-568. doi:10.1016/S0959-4752(02)00025-7

Facilitating diagnostic competences in higher education - A meta-analysis in medical and teacher education/Chernikova O. et al. Educational Psychology Review. 2020. Vol. 32. Issue 1. P. 157-196. doi:10.1007/s10648-019-09492-2

Hamel G., Prahalad C. K. The core competence of the corporation. Harvard Business Review. 1990. Issue May-June. URL: https://hbr.org/1990/05/the-core-competence-ofthe-corporation (Last accessed: 07.07.2020).

Kallioinen O. Defining and comparing generic competences in higher education. European Educational Research Journal. 2010. Vol. 9. No. 1. P. 56-68. doi:10.2304/eerj.2010.9.1.56

Keinänena M., Ursinb J., Nissinen K. How to measure students' innovation competences in higher education: Evaluation of an assessment tool in authentic learning environments. Studies in Educational Evaluation. 2018. Vol. 58. P. 3036. doi:10.1016/j.stueduc.2018.05.007

Melnyk Yu. B., Prykhodko I. I., Stadnik A. V. Medical-psychological support of specialists' professional activity in extreme conditions. Minerva Psichiatrica. 2019. Vol. 60. No. 4. P. 158-168. doi:10.23736/S03911772.19.02025-9

Melnyk Yu., Stadnik A. Mental health of a personality: diagnostics and prevention of mental disorders. International Journal of Education and Science. 2018. Vol. 1. No. 3-4. P. 50. doi:10.26697/ijes.2018.3-4.37

Melnyk Yu., Stadnik A. Necessity of accounting the psychophysiological peculiarities of the cadets during studying in the higher military educational institutions. Modernisation of the education content in terms of the industrial and innovative development of the engineering and professional education: the materials of the International research and practical online conference. Shymkent: Orleu, 2017. P. 5-8.

Melnyk Yu. Study of trends of students' demand for the formation of competences by higher educational institutions. Science and Education. 2017. Issue 5. P. 128-134. doi:10.24195/24144665-2017-5-22

Mengual-Andrés S., Roig-Vila R., Mira J. B. Delphi study for the design and validation of a questionnaire about digital competences in higher education. International Journal of Educational Technology in Higher Education. 2016. Vol. 13. No. 12. doi:10.1186/s41239-0160009-y

Synthesizing results from empirical research on computer-based scaffolding in STEM education: A meta-analysis/Belland B. R. et al. Review of Educational Research. 2017. Vol. 87. Issue 2. P. 309-344. doi:10.3102/0034654316670999.
References

Artiushyn, H. M. (2016). Intehratsiia fakhovykh i psykholohichnykh skladovykh u strukturi profesiinoi kompetentnosti spivrobitnykiv orhaniv sektoru bezpeky ta oborony Ukrainy [Integration of professional and psychological components in the structure of professional competence of employees of the security and defense sector of Ukraine]. Profesiina osvita: problemy $i$ perspektyvy - Professional education: problems and prospects, 10, 5-11. [in Ukrainian]

Drach, I. (2013). Kompetentnist fakhivtsia yak teoretychna problema [Competence of a specialist as a theoretical problem]. Nova pedahohichna dumka - New pedagogical thought, 3, 41-44. [in Ukrainian]

Kostina, V. V. (2016). Etnizatsiia osvitnoho seredovyshcha pidhotovky maibutnikh fakhivtsiv sotsialnoi sfery yak umova pidvyshchennia yikh profesiinoi kompetentnosti $\mathrm{u}$ roboti $\mathrm{z}$ dezadaptovanymy ditmy ta moloddiu [Ethnicization of the educational environment of training future specialists in the social sphere as a condition for increasing their professional competence in working with maladapted children and youth]. In M. P. Vasylieva (Ed.), Pedahohizatsiia sotsialnoho seredovyshcha $v$ roboti $z$ riznymy sotsialnymy subiektamy Pedagogization of the social environment in working with different social subjects (pp. 5961). Kharkiv, Ukraine: KhNPU. [in Ukrainian]

Lemeshko, O. V. (2016). Profesiina kompetentnist yak skladova hotovnosti maibutnikh ofitserivprykordonnykiv do lokalizatsii nestandartnykh sytuatsii v punktakh propusku cherez derzhavnyi kordon [Professional competence as a component of the readiness of future border guards to localize unusual situations at border crossings]. Viiskova osvita Natsionalnoho universytetu oborony Ukrainy imeni Ivana Cherniakhovskoho - Military education of the Ivan Chernyakhovsky National University of Defense of Ukraine, 1(33), 42-49. [in Ukrainian]

Melnyk, Yu. B., \& Stadnik, A. V. (2020). Vplyv nehatyvnykh psykholohichnykh faktoriv na efektyvnist roboty viiskovosluzhbovtsiv v ekstremalnykh umovakh [Impact of negative psychological factors on the effectiveness of military-men in extreme conditions]. International Journal of Education and Science, 3(2), 40. doi:10.26697/ijes.2020.2.26 [in Ukrainian]

Osodlo, V. I. (2012). Psykholohiia profesiinoho stanovlennia ofitsera [Psychology of professional becoming an officer]. Kyiv: Zoloti Vorota. [in Ukrainian]

Stadnik, A. V., Riutin, V. V., Mirshuk, O. Ye., \& Prokopenko, Yu. O. (2018). Shliakhy formuvannia profesiinykh kompetentnostei kursantiv psykholohichnoho profiliu u protsesi navchannia [Ways of forming professional competencies of cadets of psychological profile 
in the learning process]. Chest $i$ zakon - Honor and Law, 3, 45-50. [in Ukrainian]

Yahupov, V. V. (2002). Pedahohika [Pedagogy]. Kyiv: Lybid. [in Ukrainian]

Alcalá, D. H., Picos, A. P., \& Pastor, V. L. (2019). The impact of formative and shared or coassessment on the acquisition of transversal competences in higher education. Assessment \& Evaluation in Higher Education, 44(6), 933945. doi:10.1080/02602938.2018.1530341

Dochy, F., Segers, M., van den Bossche, P., \& Gijbels, D. (2003). Effects of problem-based learning: A meta-analysis. Learning and Instruction, 13(5), 533-568. doi:10.1016/S0959-4752(02)00025-7

Chernikova, O., Heitzmann, N., Fink, M. C., Timothy, V., Seidel, T., \& Fischer, F. (2020). Facilitating diagnostic competences in higher education - A meta-analysis in medical and teacher education. Educational Psychology Review, 32(1), 157196. doi:10.1007/s10648-019-09492-2

Hamel, G., \& Prahalad, C. K. (1990). The core competence of the corporation. Harvard business review, May-June. Retrieved from https://hbr.org/1990/05/the-core-competence-ofthe-corporation

Kallioinen, O. (2010). Defining and comparing generic competences in higher education. European Educational Research Journal, 9(1), 56-68. doi:10.2304/eerj.2010.9.1.56

Keinänena, M., Ursinb, J., \& Nissinen, K. (2018). How to measure students' innovation competences in higher education: Evaluation of an assessment tool in authentic learning environments. Studies in Educational Evaluation, 58, 30-36. doi:10.1016/j.stueduc.2018.05.007

Melnyk, Yu. B., Prykhodko, I. I., \& Stadnik, A. V. (2019). Medical-psychological support of specialists' professional activity in extreme conditions. Minerva Psichiatrica, 60(4), 158168. doi:10.23736/S0391-1772.19.02025-9

Melnyk, Yu., \& Stadnik, A. (2018). Mental health of a personality: Diagnostics and prevention of mental disorders. International Journal of Education and Science, 1(3-4), 50. doi:10.26697/ijes.2018.3-4.37

Melnyk, Yu., \& Stadnik, A. (2017). Necessity of accounting the psychophysiological peculiarities of the cadets during studying in the higher military educational institutions. In L. T. Iskakova, \& Sh. N. Erheshbaeva (Eds.), Modernisation of the education content in terms of the industrial and innovative development of the engineering and professional education (pp. 5-8). Shymkent, Kazakhstan: Orleu.

Melnyk, Yu. (2017). Study of trends of students' demand for the formation of competences by higher educational institutions. Science and Education, 5, 128-134. doi:10.24195/24144665-2017-5-22

Mengual-Andrés, S., Roig-Vila, R., \& Mira, J. B. (2016). Delphi study for the design and validation of a questionnaire about digital competences in higher education. International Journal of Educational Technology in Higher Education, 13(12). doi:10.1186/s41239-0160009-y

Belland, B. R., Walker, A. E., Kim, N. J., \& Lefler, M. (2017). Synthesizing results from empirical research on computer-based scaffolding in STEM education: A meta-analysis. Review of Educational Research, 87(2), 309-344. doi:10.3102/0034654316670999.

\section{Psychological and Pedagogical Grounds for the Formation of Professional Competences of Future Officers-Psychologists}

\author{
Babak S. A. ${ }^{1}$, Stadnik A. V. ${ }^{1,2}$, Melnyk Yu. B. ${ }^{2,3}$ \\ ${ }^{1}$ Kharkiv National University of Internal Affairs, \\ Ukraine \\ ${ }^{2}$ Kharkiv Regional Public Organization "Culture of \\ Health" (KRPOCH), Ukraine \\ ${ }^{3}$ Scientific Research Institute KRPOCH, Ukraine
}

\begin{abstract}
Background: Training of future officers-psychologists at the military department of institution of higher education (IHE) involves the formation of a number of competences, one of the most important is professional competence. All this presupposes the solution of certain tasks concerning the quality training of officers-psychologists, the improvement of teaching in military IHE and the improvement of the organization and methods of work with the personnel of the Armed Forces of Ukraine.

The aim of the study: To determine the psychological and pedagogical grounds for the formation of professional competences of future officerspsychologists during training at the military department of IHE and on this basis to develop a model for the formation of professional competence.

Materials and Methods: The research methodology was based on competence approach to the formation of professionally significant qualities of future officerspsychologists. Analysis and generalization of psychological-pedagogical, scientific-methodical literature on the problems of organization of training at the military department of IHE, development of a model of professional competence of the future military psychologist for solving competence-oriented tasks in the educational process.
\end{abstract}

Results: It was determined that the specifics of the professional activity of future officers-psychologists has a stable and powerful psychological-pedagogical component, which contains: psychological diagnostics, psychological prognosis, psychological prevention, psychological counseling, psychological correction, psychological rehabilitation, psychological selection and placement of personnel, educational and propaganda, research work, psychological expertise. The structure of the components of the officerpsychologist's professional competence was specified: general military, psychological-pedagogical, socialcommunicative, moral-ethical, acmeological, 
organizational-legal, scientific-technical, and physical. The psychological and pedagogical grounds for the formation of professional competence of a psychologist officer were clarified, which are the content of the conditional component of the model of professional competence of the future military psychologist and contain three interrelated blocks: target, semantic, effective.

Conclusions: The defined psychological and pedagogical grounds for the formation of the officer- psychologist's professional competence are considered as effective tools of preparation of the officerpsychologist. The proposed model of professional competence of the future military psychologist is open, constantly evolving and can be supplemented with new components if necessary.

Keywords: education, psychologists, officers, competence, model.

\section{Cite this article as:}

Babak, S. A., Stadnik, A. V., \& Melnyk, Yu. B. (2020). Psykholoho-pedahohichni zasady formuvannia profesiinykh kompetentnostei maibutnikh ofitseriv-psykholohiv [Psychological and Pedagogical Grounds for the Formation of Professional Competences of Future Officers-Psychologists]. International Journal of Education and Science, 3(3), 2028. doi:10.26697/ijes.2020.3.4 [in Ukrainian]

The electronic version of this article is complete. It can be found online in the IJES Archive https://ijes.culturehealth.org/en/archive and in the KRPOCH Publishing Repository https://ekrpoch.culturehealth.org/handle/lib/58 This is an Open Access article distributed under the terms of the Creative Commons Attribution License, which permits unrestricted use, distribution, and reproduction in any medium, provided the original work is properly cited (http://creativecommons.org/licenses/by/4.0/deed.en). 